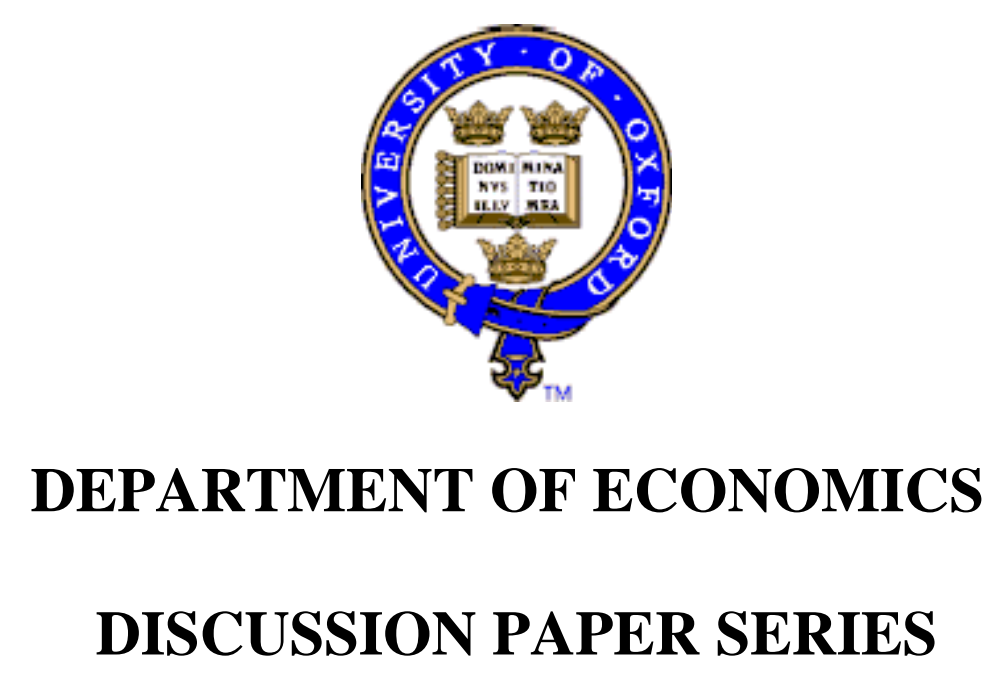

THE CAUSES OF UNEMPLOYMENT IN INTERWAR AUSTRALIA

N.H. Dimsdale and N. Horsewood

Number 81

October 2001

Manor Road Building, Oxford OX1 3UQ 


\title{
The Causes of Unemployment in Interwar Australia ${ }^{*}$
}

\author{
by
}

\author{
N H Dimsdale \\ Queen's College, Oxford
}

\author{
N Horsewood \\ University of Birmingham
}

July 2001

\begin{abstract}
This paper examines the factors contributing to the rise in unemployment in Australia during the depression of the 1930s and to its decline in the subsequent recovery. While previous writers have generally argued that demand side variables were predominant, it has also claimed that excessive real wages created unemployment. The Layard-Nickell model, which has been used to examine the relationship between real wages and unemployment in interwar Britain, is estimated from Australian data. The results of the estimation confirm that demand side variables in the form of changes in government spending and in the terms of trade were important in both the downturn and the recovery. Although real wages affected employment and wage indexation procedures resulted in some real wage rigidity this was not a major contributor to unemployment. In addition wage indexation resulted in a high degree of flexibility of money wages, so that nominal inertia was not a problem. This is in contrast to a country, such as the UK, where wages are determined by collective bargaining rather than by formal wage regulation. No evidence was found that the much discussed decision of the Commonwealth Court to reduce real wages by $10 \%$ was effective.
\end{abstract}

Key words: Unemployment, Great Depression, Wage Indexation, Australia.

JEL Classification: $\quad$ E24, N17 and N37.

\footnotetext{
* We wish to acknowledge with gratitude the support of the Department of Economic History and of Economics in the School of Research Studies at ANU and in particular the assistance given by Professors Graeme Snooks and Bob Gregory to the visit by Nicholas Dimsdale to Canberra in 1995. Helpful comments have been received from Mark Thomas, Mary Gregory, Steve Nickell, David Vines, Max Hartwell and Keiran Sharpe. All remaining errors are the authors' responsibility.
} 


\section{Introduction}

Most writers on the Australian economy in the interwar period have argued that the depression of the 1930s was the result of external factors. These were first, the interruption of the inflow of international capital on which investment largely depended and secondly, the deterioration in the terms of trade associated with the fall in export prices. This view has been put succinctly by Giblin (1951) who states that "the immediate causes of the depression for Australia were external - the sudden stoppage of capital imports and the devastating fall in export prices". A similar conclusion has been reached by Schedvin (1970) and Boehm (1993).

While this explanation emphasizes demand factors as a cause of unemployment, there is tradition which claims that the level of real wages was a contributory factor to the severity of unemployment. This view was advanced by contemporary observers, such as Copland (1934) and by the Commonwealth Court in its attempt to reduce real wages in 1931. More recently, Valentine (1988) and Eichengreen (1988) have suggested that excessive real wages aggravated unemployment in Australia. In Golden Fetters (1992) Eichengreen argues that the rigidity of the Australian system of wage determination may have been to blame. He suggests that the indexation of money wages, designed to protect the living standards of workers, was a source of distortion. The cost of living to which many wages were linked was less flexible than export prices. When the price of exports declined sharply, the failure of money wages to adjust created problems for employers, particularly in the primary producing export sector. Thus both demand shocks and excessive real wages may have contributed to unemployment.

A related controversy has arisen in Britain, where writers, such as Benjamin and Kochin (1979) and Beenstock and Warburton (1986), have argued that supply side factors in the form of state provided unemployment benefits can explain the persistence of 
unemployment. This view is in marked contrast to the traditional Keynesian analysis, which emphasises deficient demand as the prime cause of interwar unemployment. It was also associated with external shocks, as in Howson (1975). Dimsdale, Nickell and Horsewood (1989) attempted to resolve this issue by applying the labour market model developed by Layard and Nickell (1986) and Layard, Nickell and Jackman (1991) to interwar data. The model enabled them to distinguish between the impact of demand shocks and supply side factors in the labour market. While the replacement ratio affected the real wage and unemployment, the decline in employment in the slump and its reversal in the 1930s was largely attributable to demand shocks. In particular the claim by Beenstock and Warburton that real wage moderation instigated recovery was rejected.

This paper uses a similar model to examine the role of demand and supply side factors in the Australian labour market. In assessing the causes of the depression in Australia, Gregory (1988) concludes that the role of real wages remain s controversial. The aim of this paper is to attempt to resolve this issue. Section I of the paper reviews the course of the main variables in the Australian economy, while Section II outlines the model and explains the modelling strategy. Section III reports and discusses the empirical results, with an analysis of unemployment presented in Section IV. Section V reviews the main findings, followed by a brief conclusion.

\section{Section I The Australian Economy in the Interwar Period}

The general course of the Australian economy in the interwar period is shown in

Charts 18. ${ }^{1}$ GDP at constant prices reached a peak in the mid-1920s and then levelled off (Chart 1). There is a decline from 1929/30, followed by a recovery that started in 1930/31 and gathered strength during the 1930s reaching a peak in 1937/38. The main source of the GDP 
series and the other macroeconomic data is Butlin (1977). ${ }^{2}$ According to the same source, unemployment averaged about $5 \%$ of the labour force during the $1920 \mathrm{~s}$, but rose steeply from $1929 / 30$, reaching a peak in $1931 / 32$, when $20 \%$ of the workforce was unemployed. There was then a sustained decline in unemployment to $1937 / 38$, when the unemployed rate had fallen to $7.5 \%$. The rise in unemployment is reflected in the fall in civil employment, which reached a peak in $1927 / 28$ (Chart 2) and then fell by $12.7 \%$ from $1928 / 29$ to $1931 / 32$. There was then a rebound as the economy recovered from 1931/32 to 1938/39 when civil employment rose by $28.6 \%$. By contrast, the labour force showed a fairly steady upward trend as can be observed in Chart $2 .^{3}$

During the 1920s the economy enjoyed advantageous terms of trade on account of buoyant prices of primary products, in particular wool and wheat prices, and there was a strong inflow of overseas capital. The externa 1 climate created a favourable background for economic growth, as noted by Copland (1934) and Boehm (1993). The terms of trade reached a high point in 1924/5 before going into reverse, their course broadly followed that of wool prices $^{4}$ (Chart 3). Capital imports reached a peak in 1927/28 and averaged 5\% of GDP during the 1920s (Chart 4). The terms of trade fell steeply in the Great Depression and showed only partial recovery during the 1930 s, rising to $1936 / 37$ before relapsing. Capital inflows served to finance the deficit on current account during the 1920s and their curtailment in the 1930s necessitated the achievement of approximate balance in the current account. An external liquidity crisis followed the cessation of capital imports in 1928/29 at a time when the current account deficit was growing rapidly because of the weakness of export earnings. ${ }^{5}$

When capital inflows were taking place in the 1920s, largely to finance public sector capital projects, government expenditure on goods and services showed considerable buoyancy (Chart 3). Direct expenditure on public consumption and investment rose by $27.4 \%$ from $1921 / 22$ to $1928 / 29$. The impart of the Great Depression on capital inflows and export earnings 
Chart1: Percentage Unemployed, GDP

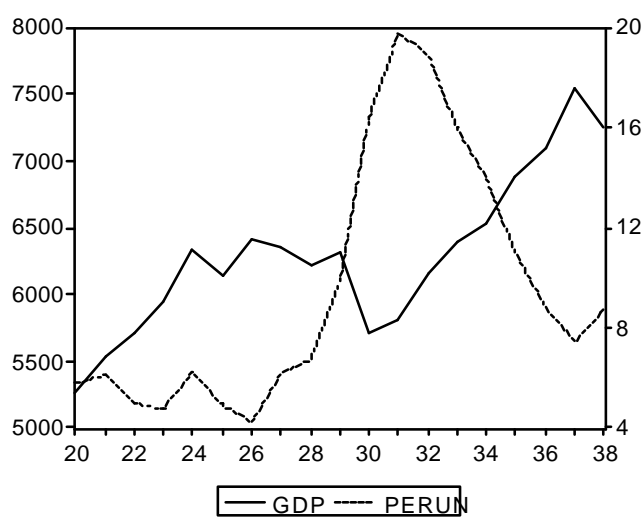

Chart 3: Government spending on goods and services and Terms of Trade

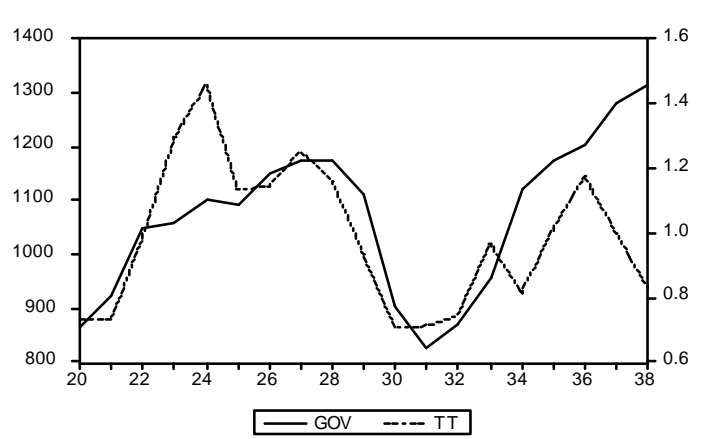

Chart 5: Real wage, Percentage Unemployed

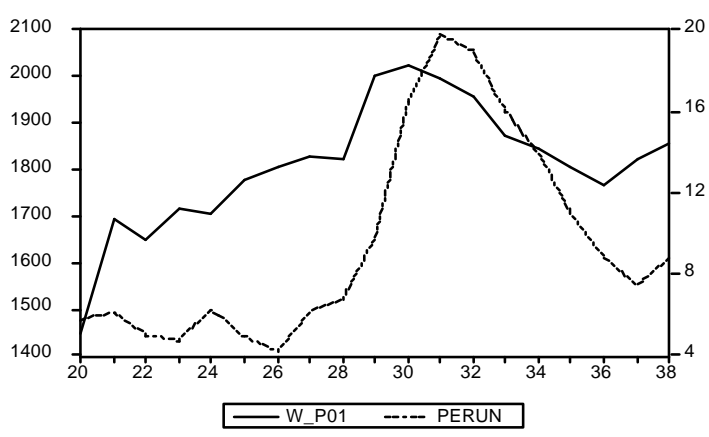

Chart 7: Award Wage, Money Wage

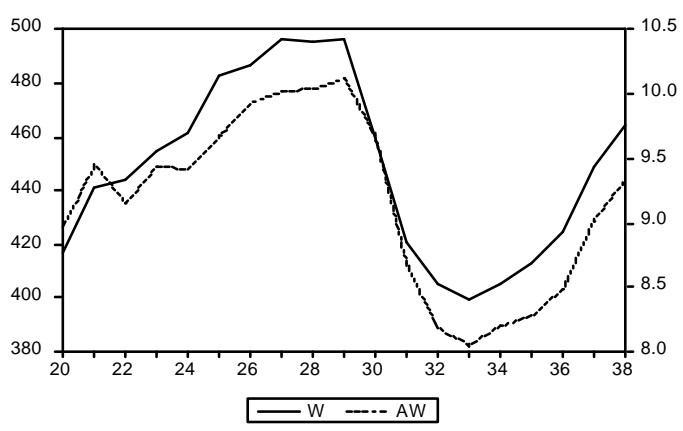

Chart 2: Civil Employment and Labour Force

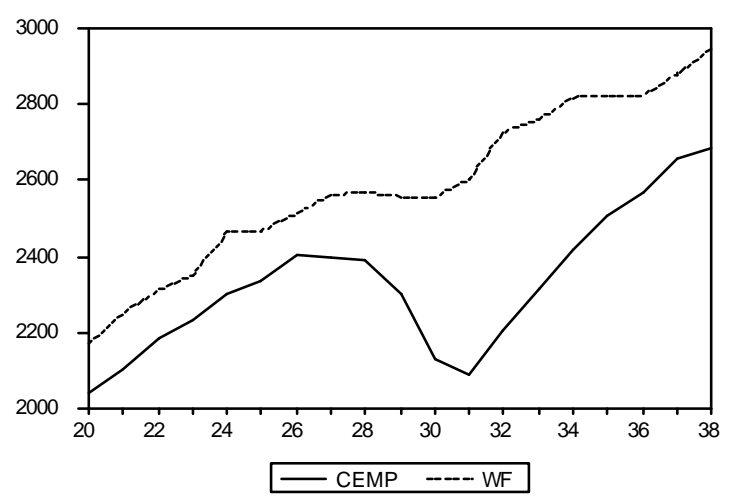

Chart 4: Current account-GDP ratio Capital inflow-GDP ratio

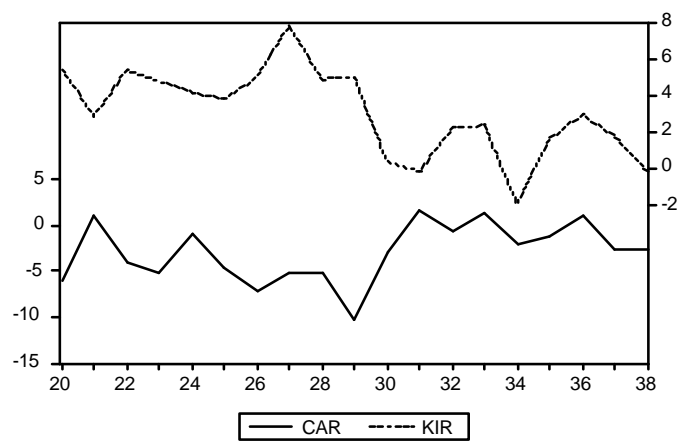

Chart 6: TFE deflator, Retail Price Index

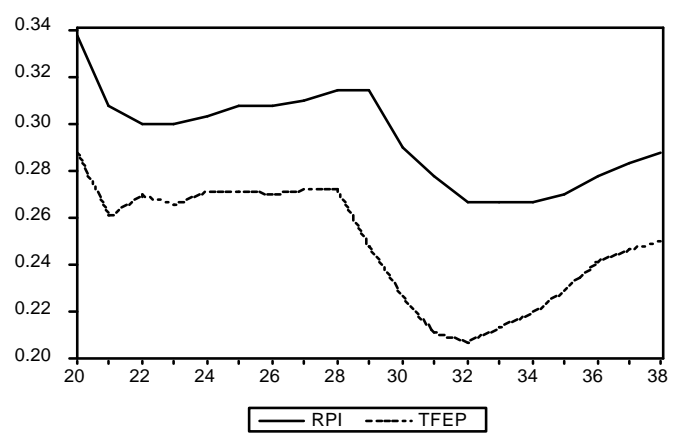

Chart 8: Real Price of Exports Real Price of Imports

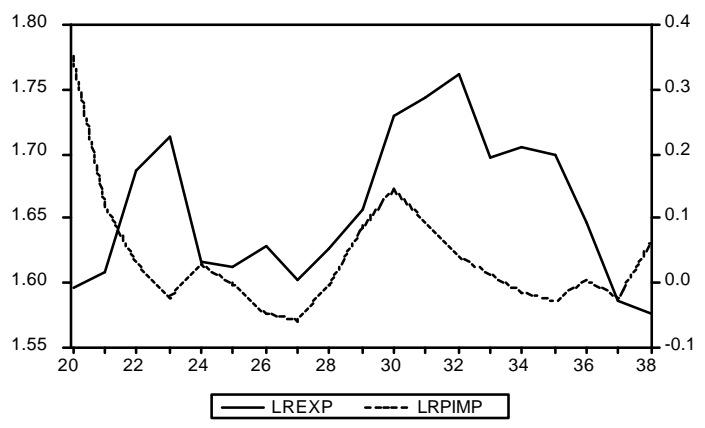


precipitated an external crisis, followed by the rapid growth of budget deficits, as discussed by Schedvin (1970) and Pincus (1988). Government expenditure was cutback under the Premiers' Plan, which aimed to restore financial stability. As a result, real government spending on goods and services declined by $25.8 \%$ from $1929 / 30$ to $1931 / 32$, the brunt of the reduction falling on capital spending, which was cut by $46.9 \%$. From 1931/32 there was a recovery in public sector spending, which rose by $59.3 \%$ to $1938 / 39$. Public sector investment increased by $77.8 \%$ during the same period, drawing on the resources of the domestic capital market in contrast to the heavy reliance on foreign capital in the 1920s, Giblin (1951).

The Layard-Nickell model focuses on the cost to the firm of employing labour, measured by money wages deflated by the output price. The real wage, measured by the money wage in manufacturing deflated by the price of final expenditure, together with unemployment is shown in Chart 5. Its components, the money wage and the total final expenditure deflator, are shown separately in Charts 6 and 7. The price of final output remained farly constant during the 1920s, after the post World War 1 deflation. It fell from $1928 / 29$ to $1932 / 33$ by $23.8 \%$, followed by a partial recovery to $1938 / 39(20.7 \%)$. The money wage rose during the 1920 s, reaching a peak in $1927 / 28$. There is a decline from $1929 / 30$ to $1932 / 33$ of $18.7 \%$ and a recovery of $14.6 \%$ to $1938 / 39$. The rising money wage in the 1920 s was associated with an upward trend in the real product wage, which rose more steeply to 1930/31 because of the decline in the output price, reflecting the weakness in export prices. The real wage then followed a generally declining trend in the 1930s, as shown in Chart 5 . The retail price index showed a larger increase than the output price index in the 1920s and continued rising to $1929 / 30$ (Chart 6). This is in contrast to the final expenditure deflator, which declined from 1928/29 under the influence of depressed export prices, excluded from the retail price index. There is a pronounced hump in the real wage deflated by the price of 
gross output in Chart 5, which reaches a peak in 1930/31, in contrast to the flatter profile of the consumption wage (money wage deflated by the retail price index).

Under the highly regulated conditions of the Australian labour market in the interwar period, the manufacturing wage was closely related to the average wage awarded by wage tribunals and other wage determining bodies. This in turn was closely related to the RPI under wage indexation arrangements, which have been described by Kenwood (1995) and Gregory et al (1988a). We therefore emphasize the link between the real retail price index, the RPI deflated by the output price, and the real output price. The RPI and the TFE deflator are shown in Chart 6. Chart 7 shows the average award wage and the money wage in manufacturing, which indicates the high degree of wage flexibility achieved under a regime of indexing wages to the cost of living. Finally, Chart 8 shows the real price of exports and imports, which are variables of potential importance in the model.

Section II

\section{A The Basic Equations of the Model}

The basic model of the labour market is derived from Dimsdale et al (1989), which draws on Layard and Nickell (1986). It consists of a labour demand equation, an equation for real wages and a price mark-up equation. In the labour demand equation, which is in $\log$ linear form, civil employment is positively related to the capital stock and negatively to the real wage, Equation (1) in Table 1. The real wage is the average money wage deflated by the price index for final expenditure. Labour demand also depends on real import prices, where import prices are deflated by the price of final expenditure. If imports largely consisted of raw materials and were therefore complementary with domestic labour, a rise in the real price of imports would reduce employment. Should imports consist largely of finished goods, 
which are competitive with domestically produced goods, a rise in real import prices would increase employment. The sign of the coefficient on real import prices is therefore ambiguous. Employment also depends on shocks to aggregate demand. The demand variables enter as shock effects rather than levels, since the basic structure of the model is neoclassical. Demand variables are included in the parameter $\sigma$. Shocks can come from both external and domestic sources, which are represented by changes in government spending and changes in the terms of trade. Other demand variables, such as the growth of world trade, may also be included in the equation.

Equation (2) is the wage equation, which explains the determination of the real wage, defined as the money wage deflated by the price of final output. It represents a bargaining equation in which the real wage is positively related to the capital stock per head of the labour force and may be positively or negatively related to the real price of imports. A rise in the level of unemployment weakens the bargaining strength of labour and therefore has a negative coefficient in the real wage equation. Bargaining strength will also be increased by a higher degree of mismatch between demand and supply in the labour market. Mismatch is measured by the change in employment in manufacturing and construction relative to the change in total employment. An increase in the ratio of employment in manufacturing and construction to total employment implies a tightening of labour market conditions. An increase in mismatch has a positive on to the bargained real wage. The bargaining strength of labour may be indicated by a conventional measure, such as trade union density, which should be positively related to the real wage. The real wage is negatively related to positive price shocks, since an unexpected rise in prices will reduce the bargained real wage due to nominal wage rigidity. Nominal inertia has been found to be an important factor in explaining real wages in interwar Britain, where wages were determined largely by collective bargaining. 
Table 1 The Basic Model of the Labour Market

Employment Equation

1. $\ln \mathrm{CEMP}=\alpha_{0}+\alpha_{1} \ln \mathrm{K}+\alpha_{2} \ln (\mathrm{W} / \mathrm{P})+\alpha_{3} \ln (\mathrm{Pim} / \mathrm{P})+\sigma$

$+\quad-\quad+$ -

1a. $\sigma=\alpha_{4} \Delta \operatorname{lnGOV}+\alpha_{5} \Delta \ln \mathrm{TT}$

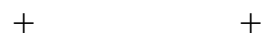

Wage Equation

2. $\ln (\mathrm{W} / \mathrm{P})=\beta_{0}+\beta_{1} \ln (\mathrm{K} / \mathrm{L})+\beta_{2} \ln (\mathrm{Pim} / \mathrm{P})+\beta_{3} \mathrm{U}+\mathrm{Z}+\beta_{4} \ln \left(\mathrm{P}^{\mathrm{e}} / \mathrm{P}\right)$

$+\quad+$ -

2a. $\quad Z=\beta_{5} \ln (\mathrm{RPI} / \mathrm{P})+\beta_{6} \mathrm{MM}+\beta_{7} \mathrm{TUD}$

$+\quad+\quad+$

Price Mark-up Equation

3. $\ln (\mathrm{P} / \mathrm{W})=\gamma_{0}+\gamma_{1} \ln (\mathrm{K} / \mathrm{L})+\gamma_{2} \ln (\mathrm{Pim} / \mathrm{P})+\gamma_{3} \sigma+\gamma_{4}\left(\mathrm{~W}^{\mathrm{e}} / \mathrm{W}\right)$

$$
+\quad+-\quad+
$$

Real RPI Equation

4. $\quad \ln (\mathrm{RPI} / \mathrm{P})=\delta_{0}+\delta_{1} \ln (\mathrm{Pex} / \mathrm{P})$

$\underline{\text { Variables }}$

CEMP

$\mathrm{K}$

$\mathrm{W}$

$\mathrm{P}$

Pim

GOV

Pex

TT

L

U

RPI

$\mathrm{MM}$

TUD

$\mathrm{D}$
Civil employment

Capital stock (excluding housing)

Wage (manufacturing)

Total final expenditure deflator

Price of imports

Government expenditure on goods \& services

Price of exports

Terms of trade (Pex/Pim)

Labour force

Unemployment (\%)

Retail price index

Mismatch

Trade union density

Dummy
$\mathrm{D}=1 \quad 1931 / 2-1938 / 9$

$\mathrm{D}=0$ elsewhere 
The variables considered so far represent economic fundamentals within the Layard Nickell model. In addition, it is necessary to take account of the wage determining arrangements, which were characteristic of interwar Australia. These have been extensively discussed in the literature as in Hancock (1969), (1972), Reddaway (1938) and more recently Gregory et al (1988a), (1988b). The average level of award wages was closely related to the cost of living, following the general adoption of indexation procedures by Federal and State wage setting tribunals. Wages in manufacturing were closely related to award wages, strictly only minimum rates, which employers were required to pay. We do not seek to model the working of this process in detail but rather to test the hypothesis that real wages in manufacturing were positively related to the real cost of living, that is the retail price index deflated by the price of final output. The wage determining procedures provided a transmission mechanism through which changes in the RPI were passed on via award wages to wages in manufacturing. In so far as only the basic wage component of the total wage was related to the cost of living and not to the secondary margin, the response of the average award wage to changes in RPI would be less than proportionate, Hancock (1969). The inclusion of real consumer prices in the wage equation is a way in which incomes policies and wage indexation may be modelled, following Layard, Nickell and Jackman (1991), and may result in real wage resistance. This serves to protect real wages against a rise in the real RPI. ${ }^{6}$ The real RPI, mismatch and trade union density are, for convenience, grouped together as wage push factors in the wage equation and are labelled $\mathrm{Z}$ in Equation (2).

The wage in manufacturing, which is our measure of the market-determined wage, responds to economic fundamentals, such as capital per head, unemployment and mismatch, as well as the decisions of wage determining bodies. It is an empirical issue as to which set of factors was more important. One implication of full wage indexation is that nominal inertia should be largely eliminated, as the real wage would be cushioned against price shocks. Also 
the inclusion of the real RPI in the wage equation should reduce the impact of real import prices on the real wage, in so far as imported goods are included in the cost of living index. Finally, we have included a dummy variable to test for the impact of the decision of the Commonwealth Court to reduce the real wage in 1931.

In Equation (3) the mark-up of prices over wages is set by firms in an imperfectly competitive product market. The mark-up is negatively related to the capital/labour ratio, since a higher degree of capital intensity implies a higher real wage and a lower mark-up. It may be affected by the real price of imports, but the sign of the coefficient is ambiguous, depending on the degree of complementary or competitiveness of imports with domestic production. The pricing decisions of firms may be responsive to the state of demand, hence the demand variable, $\sigma$, is included in the price mark-up equation with an expected positive sign. The mark-up will be reduced by an unexpected ise in money wages, if there is an element of nominal inertia in price setting.

As the real RPI enters into the wage equation, it is necessary to explain it by an additional price equation. The final expenditure deflator, which is the basic price variable in the model, includes the price of exports as well as the price of domestic production consumed at home and the price of imports, whilst the RPI excludes export prices. Hence the ratio of the RPI to the price of final output depends on the real price of exports. This relationship is modelled in the real RPI equation, which is Equation (4). A fall in the real price of exports raises the real RPI and hence the real wage via the wage equation. In this way the model can capture the relative price effects, which Eichengreen has claimed to be important in explaining unemployment. 


\section{B Modelling Strategy}

Because of the limited number of annual observations in the interwar sample, it is not feasible to use a full general-to-specific estimating methodology. Our aim is to use the data set to calibrate the model developed by Layard and Nickell, allowing the data to determine the dynamics. Restrictions have been introduced into the modelling of equations, by imposing patterns of coefficients through moving average terms and Almon lags to conserve degrees of freedom. The restrictions have been tested against an unrestricted model, in so far as the degrees of freedom permit. In each case the restrictions have been accepted by the data. The use of restrictions is largely confined to the employment equation, which has complex dynamics. Alternative specifications of the main equations are reported as well as the tests of the restrictions imposed in the preferred equations.

While the data set is restricted to a limited number of annual observations, there is a wide degree of variation in the major series as shown by the charts in Section 1. Because of the severity of the depression and the strong upturn, the sample provides a good testing ground for macroeconomic models on account of the high variance of the explanatory variables. We argue that there is a greater amount of information in an interwar data set than in many longer postwar time series. This view has been reinforced by Campos and Ericsson (1990), who emphasize that sample size is only one of several factors which contribute to the information contained in a sample. The estimated standard error of a coefficient depends on the standard error of the equation and the variance of an explanatory variable as well the sample size. Campos and Ericsson show that the information content of sixteen years of annual data on the growth of real per capita income in Venezuela is $10 \%$ greater than of forty years of US quarterly data for the same variable. The small sample size for Venezuela is offset by the greater variance per observations, as compared with the US. This argument is 
relevant to the information content of Australian interwar data, where the sample size is small, but the variance of the explanatory variables is high, enabling the standard errors of coefficients to be estimated reliably.

\section{Section III}

\section{Empirical Estimates of the Model}

\section{A The Employment Equation}

In Table 2 we present three estimates of the employment equation. The preferred equation is Equation (5). It is estimated in equilibrium-correction form and exhibits long-run constant returns to scale, so that in the long term employment varies in proportion to the capital stock. The short-run dynamic behaviour of employment depends on two lagged employment terms, which are estimated in moving average form to conserve degrees of freedom. Any restrictions, which have been imposed, are tested and the results are reported in Table 3.

Employment depends on the real output wage, which is lagged and estimated in moving average form for two periods, since this restriction is accepted by the data. The shortrun elasticity of employment with respect to the real wage is -0.282 and the long-run elasticity is -0.794 . Hence the response of employment to the real wage is relatively high. ${ }^{7}$ The demand side variables are the change in government spending on goods and services, $\Delta \operatorname{lnGOV}$, and the change in the terms of trade, $\Delta \operatorname{lnTT}$, defined as export price divided by import price. There is a two period Almon lag on the coefficient of $\Delta \operatorname{lnGOV}$, which has weights of 2 and 1 . The short-run elasticity of employment in response to a change in government spending is 0.603 , rising to 1.699 in the long run. 
Table 2

Employment Equation 1923/4 -1938/9

Dependent Variable $\quad \Delta \operatorname{lnCEMP}$

\begin{tabular}{|c|c|c|c|c|c|c|c|c|}
\hline \multirow[t]{2}{*}{ Equation } & \multicolumn{3}{|l|}{ (5) } & \multicolumn{3}{|l|}{ (6) } & \multicolumn{2}{|l|}{ (7) } \\
\hline & $\underline{\text { Coefficient }}$ & $\underline{\text { t-ratio }}$ & & $\underline{\text { Coefficient }}$ & $\underline{\text { t-ratio }}$ & & $\underline{\text { Coefficient }}$ & $\underline{\text { t-ratio }}$ \\
\hline Constant & 1.806 & 2.14 & & 3.016 & 3.08 & & 1.995 & 2.42 \\
\hline $\mathrm{MA}_{2}\left[\Delta \operatorname{lnCEMP}{ }_{-1}\right]$ & -0.455 & -7.20 & & -0.432 & -7.76 & & -0.483 & -7.50 \\
\hline $\ln (\mathrm{CEMP} / \mathrm{K})_{-1}$ & -0.355 & -3.63 & & -0.389 & -4.73 & & -0.352 & -3.74 \\
\hline $\mathrm{MA}_{2}\left[\ln (\mathrm{W} / \mathrm{P})_{-1}\right]$ & -0.141 & -2.30 & & & & & -0.153 & -2.56 \\
\hline $\mathrm{MA}_{2}[\ln (\mathrm{W} / \mathrm{P})]$ & & & & -0.149 & -3.21 & & & \\
\hline $\mathrm{A}_{2}[\Delta \ln \mathrm{GOV}]$ & 0.201 & 14.24 & & 0.188 & 15.30 & & 0.212 & 13.50 \\
\hline $\mathrm{MA}_{5}[\Delta \operatorname{lnTT}]$ & 0.057 & 7.00 & & 0.044 & 5.04 & & 0.054 & 6.60 \\
\hline$\Delta \ln \mathrm{WT}_{-1}$ & & & & & & & 0.003 & 1.32 \\
\hline $\mathrm{R}^{2}$ & 0.975 & & & 0.981 & & & 0.979 & \\
\hline SE & $0.67 \%$ & & & $0.57 \%$ & & & $0.64 \%$ & \\
\hline DW & 2.56 & & & 2.08 & & & 2.38 & \\
\hline $\mathrm{F}(1,9)$ & 0.93 & & $\mathrm{~F}(1,9)$ & 0.05 & & $\mathrm{~F}(1,8)$ & 0.34 & \\
\hline Chow & 0.87 & & & & & $F(3,6)$ & 0.93 & \\
\hline
\end{tabular}

$\underline{\text { Variables }}$

CEMP Civil employment (thousands)

$\mathrm{K} \quad$ Capital stock (excluding housing)

GOV Government spending on goods and services at constant prices

W Wages, annual earnings in manufacturing

$\mathrm{P} \quad$ Price of total final expenditure at market prices

TT Terms of trade (Price of exports/Price of imports at factor costs)

WT Volume of world trade

$\mathrm{MA}_{\mathrm{i}}\left[\mathrm{X}_{\mathrm{t}}\right]=\left[\mathrm{X}_{\mathrm{t}}+\mathrm{X}_{\mathrm{t}-1}+\ldots+\mathrm{X}_{\mathrm{t}-\mathrm{i}+1}\right]$

$A_{n}\left[X_{t}\right]=\left[n X_{t}+(n-1) X_{t-1}+\ldots+X_{t-n+1}\right]$ 
I. Employment Equation

A Individual restrictions

1) Moving average (2) on the real wage, $\ln \left(\frac{\mathrm{W}}{\mathrm{P}}\right)$

$\underline{\mathrm{F}} \quad \underline{\mathrm{df}}$

0.072

2) Almon lag (2) on change in government $\quad 0.236$ spending $(\Delta \ln G O V)$

3) Moving average (5) on the change in the 0.530 terms of trade $(\Delta \operatorname{lnTT})$

4) Constant returns to scale (CRS) for $\ln \left(\frac{\mathrm{CEMP}}{\mathrm{K}}\right)$

B Test of Joint Restrictions

5) Restrictions on CRS, $\ln \left(\frac{\mathrm{W}}{\mathrm{P}}\right), \Delta \operatorname{lnGOV}$

6) Restrictions on $\Delta \ln T T, \ln \left(\frac{\mathrm{W}}{\mathrm{P}}\right), \Delta \ln \mathrm{GOV}$

II $\quad$ Price mark-up Equation

7) Restriction on $\sigma$, which is entered into the price mark-up equation with the same weights as in the employment equation

All the above restrictions are accepted by the data and are imposed in the estimation of the model. 
The terms of trade variable is a five -year moving average of the change in the log of the terms of trade. The moving average can be regarded as measuring the permanent effect of a change in the terms of trade. When the change in the terms of trade is entered directly into the equation, the maximum size of the coefficient and largest t-statistic appears after a lag of three years. The existence of long lags may be explained by the delayed impact on the economy of fluctuations in the primary producing sector, which produced about $90 \%$ of exports, where exports represented about $20 \%$ of GDP. The movement in the terms of trade largely reflected the change in export prices, which determined the purchasing power of the primary producing sector and indirectly output and employment in the rest of the economy, providing $80 \%$ of civil employment. The existence of a lag between a change in export earnings and in domestic employment has been observed by Hawke (1988) for interwar New Zealand. Our findings suggest that a similar lag was present in Australia.

The basic model includes real import prices in the employment equation, but this variable was not statistically significant. This result contrasts with the finding for the UK in Dimsdale et al (1989) that civil employment was positively related to real export prices for lags up to three quarters and negatively for lags of four to six quarters. The explanation, which we favour, for the lack of significance of real import prices in the Australian case is that the complementary and competitive effects of real import prices on employment tended to offset each other. In he UK imports consisted largely of food and raw materials, which were complementary to domestic production. In Australia there was a higher proportion of finished commodities, which were competitive with domestic production, as shown by Gilbert (1958). Since the sign of the coefficient is ambiguous in the theoretical specification, the coefficient could well be non-significant in the estimated equation.

Alternative specifications of the employment equation are shown in Table 2. In Equation (6) the real wage enters contemporaneously rather than with a lag of one period. We 
prefer the lagged specification, since employment responds to a predetermined real wage rather than being simultaneously determined with it. Equation (7) includes the change in world trade as an additional demand side variable, but this was not found to statistically significant. The results of testing the various restrictions, which have been discussed, are set out in Table 3. Each of the individual restrictions imposed are accepted by the data. Test of joint restrictions are also reported and are found to be acceptable. They are as general as a limited data set allows.

\section{B The Wage Equation}

The wage equation is shown in Table 4 and is estimated in levels as no lags of the dependent variable were found to be significant. Two equations are shown, one estimated by OLS and the other using instrumental variables. Our preferred equation is the OLS estimate, while the instrumental variable estimation is regarded as supportive, since the differenc es between the equations are slight. The real wage is positively related to the capital/labour ratio, which is lagged by one year to ensure that it is predetermined. A higher level of mismatch should raise wage pressure at a given level of unemployment and have a positive coefficient in the wage equation, as found in Equation (8). The capital/labour ratio and mismatch are shown in Chart 9. We also find that the lagged unemployment has a significantly negative effect on the real wage.

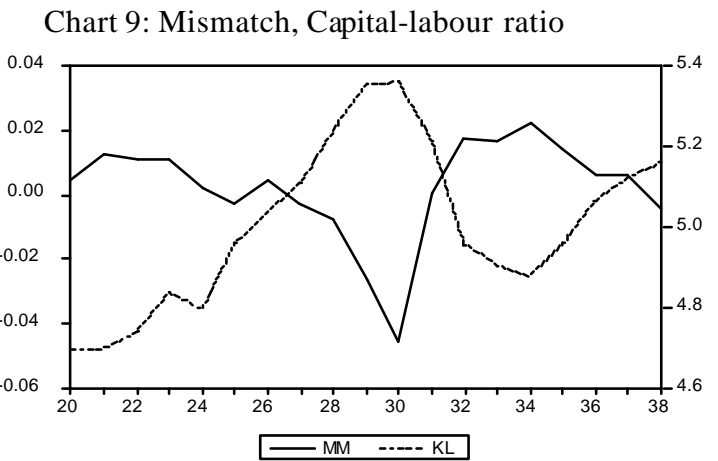


The variables considered so far have been the economic factors, entering into the standard version of the Layard-Nickell model, which explains real wages within a framework of collective bargaining. The institutional determination of wages was a major feature of the Australian interwar labour market. The link between wages setting and prices is tested by including the real retail price index, that is the RPI deflated by the price of final output, as a variable in the wage equation. It is found to be highly significant with a coefficient of 0.822 . The coefficient is less than unity, which is appropriate as only the basic component of the total wage was indexed to the cost of living. The secondary component of the award wage was relative ly unresponsive to changes in the cost of living as shown by Hancock (1969). The inclusion of the real consumer price index in the wage equation is the way in which indexation of wages is modelled in Layard, Nickell and Jackman (1991) and contributes to real wage resistance. Such rigidity is normally temporary but could be permanent with powerful institutional backing, as in interwar Australia. The inclusion of the real RPI reduces the scope for real import prices to influence the real wage, as this effect is included through the import price component of the RPI. Real import prices are found to play only a small role in determining the real wage in contrast to their much greater influence in the UK. In addition, nominal inertia, measured by the response of the real wage to unexpected changes in prices, is found to be insignificant in the wage equation. This result contrasts strongly with the major role of nominal inertia in explaining real wage behaviour in the UK. ${ }^{8}$ The result is not surprising in view of the prevalence of wage indexation in Australia, which should insulate wage earners against unexpected price changes. 
Table 4

Wage Equation 1923/4 -1938/9

Dependent Variable $\ln (\mathrm{W} / \mathrm{P})$

Equation

(8)

OLS

t-ratio

$\underline{\text { Coefficient }}$

6.697

20.84

6.737

14.91

Constant

0.472

2.27

0.445

$\ln U_{-1}$

$-0.036$

$-2.94$

$-0.037$

$-2.45$

$\mathrm{MM}_{-1}$

0.987

1.99

0.985

1.99

$\ln (\mathrm{RPI} / \mathrm{P})$

0.822

5.64

0.851

3.13

$\ln (\mathrm{Pim} / \mathrm{P})$

0.237

1.63

0.230

1.47

$\ln (\mathrm{Pim} / \mathrm{P})_{-1}$

$-0.146$

$-3.11$

$-0.148$

$-2.89$

$\mathrm{R}^{2}$

0.975

SSE

$1.07 \%$

DW

2.58

$1.07 \%$

2.58

LM

$\mathrm{F}(1,8) \quad 2.04$

Chow

$\mathrm{F}(3,6) \quad 0.71$

$\mathrm{n}=16$

Notes

1. Additional instruments for Equation (9) $\ln (\mathrm{Pim} / \mathrm{P})_{-1}, \ln (\mathrm{RPI} / \mathrm{P})_{-1}$

2. Test for inclusion of TUD in Equation (8) $\mathrm{t}=1.38$

3. Test for Commonwealth Court Dummy in Equation (8)
$\mathrm{D}=1 \quad 1931-38$
0 Otherwise
$\mathrm{t}=0.0$
$\mathrm{D}=1 \quad 1931-34$
0 Otherwise
$\mathrm{t}=0.0$

$\underline{\text { Additional Variables }}$

L Labour force (thousands)

RPI Retail price index

U Percentage unemployment

MM Mismatch, calculated as the proportion of employment in manufacturing and construction to total employment

Pim Price of imports 
We have also estimated the wage equation by instrumental variables, since the real RPI is an endogenous variable in the model. The instrumental variable estimates are, as previously noted, substantially the same as the estimates of the OLS equation. Another variable, which has been included in the preferred equation, is trade union density which was found to be non-significant $(\mathrm{t}=1.38) .{ }^{9}$ The inclusion of a dummy variable to test the impact of the decision of the Commonwealth Court in 1931 to reduce the real wage by $10 \%$ was totally non-significant.

\section{The Price Equations}

There are two price equations in the model. The price mark-up equation and the equation for the real RPI. The results of estimating the price mark-up equation are shown in Table 5. The capital/labour ratio has the expected negative sign, as higher capital intensity is associated with a reduced mark-up. Demand factors, represented by $\sigma$, which is a weighted average combination of the demand shock variables included in the employment equation, have a strongly positive effect on the mark-up, if entered with a two-period lag. When entered unlagged, the variable is not significant. There is evidence that the response of profit margins to changes in demand is positive and lagged. ${ }^{10}$ It may be noted that Layard and Nickell (1986) found a one-year lag for postwar Britain. Price adjustment was slow in comparison with the rapid adjustment of nominal wages through indexation procedures. Changes in real import prices enter with a negative sign, which is evidence of nominal inertia in price setting. The demand variable, $\sigma$, has been introduced using the weights estimated in the employment equation for changes in real government spending and the terms of trade. To test this restriction, the variables were entered independently into the price equation. The test statistics are reported in Table 3 and confirm that the restriction is accepted by the data. 
Table 5

Dependent Variable
Equation

Equation

Constant

$\ln (\mathrm{K} / \mathrm{L})_{-1}$

$\sigma$

$\sigma_{-2}$

$\Delta \ln (\mathrm{Pim} / \mathrm{P})$

$\Delta \ln (\mathrm{Pim} / \mathrm{P})_{1}$

$\Delta \ln (\mathrm{Pim} / \mathrm{P})_{2}$

$\mathrm{R}^{2}$

SE

DW

LM

Chow $\mathrm{F}(4,8)$

\section{Price Mark-up Equation}

$\ln (\mathrm{P} / \mathrm{W})$

(10)

$\frac{\text { Coefficient }}{-6.248} \quad \frac{\text { t-ratio }}{-25.31}$

(11)

$\frac{\text { Coefficient }}{-6.00} \quad \frac{\text { t-ratio }}{-8.13}$

(12)

$\frac{\text { Coefficient }}{-6.40} \quad \frac{\text { t-ratio }}{-9.99}$

$-0.944$

$-2.08$

$-0.702$

$-1.78$

0.194

0.77

0.296

1.23

4.49

$-3.24$

$-0.344$

$-0.049$

$-2.08$

$-0.153$

$-1.47$

0.820

0.846

2.48

2.30

1.64

0.34

$F(3,9) \quad 0.83$
Table 6

Dependent Variable

Equation

Constant

D29

$\mathrm{MA}_{3}\left[\ln (\mathrm{Pex} / \mathrm{P})_{-1}\right]$

$\ln (\mathrm{RPI} / \mathrm{P})_{-1}$

$\Delta_{2} \ln (\mathrm{RPI} / \mathrm{P})_{-1}$

$\mathrm{R}^{2}$

SE

DW

LM

Chow

\section{Real RPI Equation 1923/4 -1938/9}

$\Delta \ln (\mathrm{RPI} / \mathrm{P})$

(13)

$\underline{\text { Coefficient }}$

0.084

0.079

$-0.0266$

$-0.492$

0.367

0.944

$0.827 \%$

2.31

0.927

$\begin{array}{ll}\mathrm{F}(1,10) & 0.927 \\ \mathrm{~F}(4,7) & 1.102\end{array}$

Additional Variables: Pex $=$ Price of exports 
The second price equation relates the real RPI to the price of exports. The results of the estimation are shown in Table 6. The real RPI adjusts rapidly to its equilibrium level on account of the large coefficient on the equilibrium-correction term in the equation. In equilibrium the real RPI depends on the real price of exports, which enters as a three-year moving average. This implies a long-run coefficient of 0.162 for the real export price, which is not implausible in view of the ratio of exports to GDP of $18 \%$ in 1928/29. A dummy variable for 1929/30 is found to be strongly significant and is included for data reasons. There is a marked divergence between the RPI and the GDP deflator in 1929/30, as discussed in Butlin (1977). He finds that the implicit deflators for national income aggregates are not consistent with the cost of living index. Butlin prefers the implicit price index to the RPI in deflating nominal aggregates. This issue of data consistency is highlighted by the strongly significant dummy variable for $1929 / 30$ found in our equation. It may be noted that the inclusion of a dummy variable for 1929/30 in the wage equation is not statistically significant, $(\mathrm{t}=-0.263)$. This equation is not affected by the data problem, which Butlin has emphasized.

\section{Section IV The Analysis of Unemployment}

The model can be used to explain the determinants of unemployment. We are concerned with the impact of changes in the exogenous variables on unemployment when the dynamic effects arising from lagged dependent variables have been removed. We then examine how changes in unemployment between benchmark dates can be explained by changes in the exogenous variables. The suppression of dynamic effects means that the change in unemployment will be overstated in both the recession and the recovery as the 
dampening effects of the lagged dependent variable have been removed. The resulting change in unemployment is designated as to the change in medium-term employment. The long-run solution to the employment equation is obtained from Equation (5), the preferred equation in Table 2 , by setting the dynamic terms for the dependent variable equal to zero, $\Delta \operatorname{lnCEMP}=$ 0 , for all periods.

$$
\ln \left(\frac{\mathrm{CEMP}}{\mathrm{K}}\right)=5.087+1.699 \Delta \ln \mathrm{GOV}+1.161 \Delta \operatorname{lnTT}-0.794 \ln \left(\frac{\mathrm{W}}{\mathrm{P}}\right)
$$

Expressed in terms of unemployment and introducing $\sigma$ it becomes:

$$
\mathrm{U}=-\ln \left(\frac{\mathrm{CEMP}}{\mathrm{L}}\right)=5.087+\ln \left(\frac{\mathrm{K}}{\mathrm{L}}\right)+0.794 \ln \left(\frac{\mathrm{W}}{\mathrm{P}}\right)-2.817 \sigma
$$

where $\sigma=\frac{1.699 \Delta \ln \mathrm{GOV}+1.161 \Delta \ln \mathrm{TT}}{2.817}$

The long-run solution to the wage equation (8) is given by:

$$
\begin{aligned}
\ln \left(\frac{\mathrm{W}}{\mathrm{P}}\right)= & 6.697+0.472 \ln \left(\frac{\mathrm{K}}{\mathrm{L}}\right)-0.036 \ln \mathrm{U}+0.987 \mathrm{MM}+0.822 \ln \left(\frac{\mathrm{RPI}}{\mathrm{P}}\right) \\
& +0.383 \Delta \ln \left(\frac{\mathrm{Pimp}}{\mathrm{P}}\right)
\end{aligned}
$$

Setting the difference terms $\Delta_{2} \ln \left(\frac{\mathrm{RPI}}{\mathrm{P}}\right)$ in the real RPI equation (13) to zero, its long-run solution is given by:

$$
\ln \left(\frac{\mathrm{RPI}}{\mathrm{P}}\right)=0.171-0.162 \ln \left(\frac{\mathrm{Pex}}{\mathrm{P}}\right)
$$

Substituting for $\ln \left(\frac{\mathrm{RPI}}{\mathrm{P}}\right)$ in the wage equation and for the real wage in the unemployment equation, unemployment is given by: 


$$
\begin{aligned}
\mathrm{U}+0.029 \ln \mathrm{U}= & -0.118-0.625 \ln \left(\frac{\mathrm{K}}{\mathrm{L}}\right)+0.784 \mathrm{MM}+0.304 \Delta \ln \left(\frac{\text { Pimp }}{\mathrm{P}}\right) \\
& -2.187 \sigma-0.106 \ln \left(\frac{\mathrm{Pex}}{\mathrm{P}}\right)
\end{aligned}
$$

This equation is used to breakdown the elements contributing to the changes in unemployment. Taking changes gives:

$$
\begin{aligned}
\Delta \mathrm{U}+0.029 \frac{\Delta \mathrm{U}}{\overline{\mathrm{U}}} & =-0.625 \Delta \ln \left(\frac{\mathrm{K}}{\mathrm{L}}\right)+0.784 \Delta \mathrm{MM}+0.304 \Delta^{2} \ln \left(\frac{\mathrm{Pimp}}{\mathrm{P}}\right) \\
& -2.187 \Delta \sigma-0.106 \Delta \ln \left(\frac{\mathrm{Pex}}{\mathrm{P}}\right)
\end{aligned}
$$

The above equation can be written as:

$$
\begin{gathered}
\Delta \mathrm{U}=\left[1+\frac{0.029}{\overline{\mathrm{U}}}\right]^{-1}\left\{-0.625 \Delta \ln \left(\frac{\mathrm{K}}{\mathrm{L}}\right)+0.784 \Delta \mathrm{MM}+0.304 \Delta^{2} \ln \left(\frac{\mathrm{Pimp}}{\mathrm{P}}\right)\right. \\
\left.-2.187 \Delta \sigma-0.106 \Delta \ln \left(\frac{\mathrm{Pex}}{\mathrm{P}}\right)\right\}
\end{gathered}
$$

The resulting Equation (20) explains unemployment in terms of its basic determinants. The contribution of each variable to the explanation of the change in unemployment during the downturn and the recovery is shown in Table 7. Starting and ending points are averaged over two adjacent years, so that the mean of $1928 / 29$ and $1929 / 30$ is the starting point and the mean of $1931 / 32$ and $1932 / 33$ is the end of the period of contraction, and similarly for the upturn. Table 7 suggests that the demand variables included in $\sigma$ had a powerful depressing effect in the slump, accounting for $64 \%$ of the total positive effect on unemployment. The combined contribution of the capital/labour ratio, mismatch and real export prices was less important. In the recovery the impact of the change in demand variables was even stronger, accounting for $89 \%$ of the decline in unemployment. Real export prices made a smaller contribution to explaining unemployment, that is $17.8 \%$ in recession and $7.6 \%$ in recovery. 
While demand side effects predominated, the influence of the real price of exports on the real wage and unemployment in the downturn was still important.

\section{Table 7 Change in Medium-Term Unemployment and its Determinants}

Change in the Unemployment Rate

$1928 / 29-1931 / 32$

$\begin{array}{lc}\Delta \ln (\mathrm{K} / \mathrm{L}) & 2.01 \\ \Delta \mathrm{MM} & 1.60 \\ \Delta \ln (\mathrm{Pex} / \mathrm{P}) & 1.74 \\ \Delta^{2} \ln (\mathrm{Pim} / \mathrm{P}) & -0.44 \\ \Delta \sigma & 8.69\end{array}$

Sum of medium term effects 13.60

Actual change

$\underline{1931 / 32-1937 / 38}$

$\begin{array}{lr}\Delta \ln (\mathrm{K} / \mathrm{L}) & -0.32 \\ \Delta \mathrm{MM} & -0.19 \\ \Delta \ln (\mathrm{Pex} / \mathrm{P}) & -1.35 \\ \Delta^{2} \ln (\mathrm{Pim} / \mathrm{P}) & -0.16 \\ \Delta \sigma & -15.82\end{array}$

Sum of medium term effects -17.83

Actual change $\quad-11.19$

In an earlier paper, Dimsdale and Horsewood (1996), we used an alternative version of the Layard-N ickell model, which included the real award wage rather than the real RPI in the wage equation. We found that both demand and supply factors were influential in the downturn and the recovery. While the preponderance of demand shocks was less than in the results reported here, our conclusions are fairly robust with respect to alternative versions of the model. 
We have referred to the test proposed by Campos and Ericsson (1990) for the informational content of data sets. We compare the standard errors of the coefficient on the real wage in the employment equation for interwar Australia and postwar Britain for the Layard-N ickell model. The standard error for each coefficient is given by the corresponding diagonal element of the variance-covariance matrix for $\hat{\beta}$ and depends on the estimated error variance, the sample size and the average variance of an observation $x_{t}$ on the explanatory variable. We find that the Australian coefficient is as well determined as the coefficient in the British equation from Layard and Nickell (1986). This is despite the British sample containing nearly twice as many observations. The smaller number of observations for the Australian data set is offset by the greater variability of the real wage and the lower standard error of the equation as shown in Table 8 . This result confirms that the interwar data set contains considerable information despite the restricted sample size.

\section{Table 8 Information Content of Data Sets}

$\begin{array}{llllllr}\text { Country } & \text { Sample } & \text { Obs } & \operatorname{SD}\left(\mathrm{x}_{\mathrm{t}}\right) & \Sigma \mathrm{x}_{\mathrm{t}}{ }^{\prime} \mathrm{x}_{\mathrm{t}} & \hat{\sigma} & \sqrt{\hat{\sigma}^{2}\left(\mathrm{X}^{\prime} \mathrm{X}\right)^{-1}} \\ \text { Australia } & 1923 / 4-38 / 9 & 16 & 0.0337 & 0.0182 & 0.0067 & 0.0497 \\ \text { UK } & 1953-83 & 30 & 0.0282 & 0.0239 & 0.0077 & 0.0498\end{array}$

\section{Section V Evaluation of Results}

The model which we have estimated, is intended to be useful in distinguishing between the impact of demand shocks on the economy and the consequences of methods of wage determination, which may have kept real wages at too high a level. Demand factors 
have been emphasized by a series of writers, such as Copland, Walker and Schedvin. They have pointed to the decline in the terms of trade and the closing off of external capital flows in precipitating the downturn. While external borrowing is not included as a variable in the model, there was a close connection between public sector investment and overseas loans. Schedvin (1970) comments that "When the London capital market was closed [to Australia] in 1929, the multiplier effect of reduced government expenditure was more immediate and damaging than the fall in farm incomes and an even greater cause of unemployment than the fall in export prices was the virtual cessation of public works expenditure". The close connection between loanfinanced public expenditure and overseas borrowing was pointed out by Walker (1933) and Copland (1934). Following reductions in public sector investment in 1929/30, reductions in current expenditure were made to reduce 'adjustable' public spending by $20 \%$ under the Premiers' Plan. Pincus (1988). Schedvin argued that the Premiers' Plan was “unambiguously deflationary for it involved a sharp decline in government expenditure and hence in aggregate demand".

The collapse of the terms of trade also had adverse effects on employment, but there is evidence of a lag between changes in the terms of trade and their impact on employment. This lag can be attributed to the delayed effect of changes in primary commodity prices in affecting rural incomes and expenditure on goods and services produced in the rest of the economy. Copland (1934) observed that 'if exporters' incomes are low, their capacity to purchase goods from sheltered and protected industries will be reduced". Hawke (1988) found that in New Zealand the decline in rural incomes in the Great Depression preceded the decline in activity in manufacturing and construction. Our results suggest that a similar process operated in Australia.

In the employment equation the product wage is found to have statistically significant effects on civil employment. Effects of real wages on employment have also been found by 
Valentine (1988) and Eichengreen (1988). Some contemporary observers, such as Copland, considered the role of real wages to be important. He expressed this view in his evidence to the Commonwealth Arbitration Court in 1930 and his opinion was reflected in the report of the Court, which argued that wage reductions were essential to prevent a further rise in unemployment, Shann and Copland (1931). The wage variable is the wage in manufacturing, which is the widest measure available to us for this period. We find that a major determinant of the real product wage is the real RPI. This is not surprising in view of the prevalence of indexation procedures, which related wages to the cost of living on a quarterly basis. Variation in the ratio of the RPI to the price of final output created a wedge, in the terminology of the Layard-Nickell model, and gave rise to real wage resistance. Indexation meant that wages were rapidly adjusted for price movements so that workers were protected against unexpected price changes. This implied that in a period of falling prices money wages showed downward flexibility, in contrast to the high degree of nominal inertia found by Dimsdale et al (1989) for wages in interwar Britain.

The award wage was closely related to the cost of living but the rates set in this way were minima. Earnings could also be affected by general economic factors, such as the degree of capital intensity and the level of unemployment. We found evidence for this in the wage equation, where the capital/labour ratio, unemployment, and mismatch in the labour market affect the real wage. This result suggests that market forces played some role in explaining the real wage and in particular, the capital/labour ratio was of importance.

Real import prices were found to be less important than for interwar Britain. In the employment equation real import prices were not found to be statistically significant in contrast to the strong effects found in Britain. We argue that this was due to the complementary and competitive effects of import prices offsetting each other in Australia. Although the real price of imports entered the wage equation, it was not as important as in the 
British wage equation. This is not surprising in view of the presence of the real RPI in the Australian equation, which includes the price of imported goods. Whereas the replacement ratio featured in the British wage equation, absence of a comprehensive unemployment insurance scheme in Australia meant that this variable did not enter its Australian counterpart. ${ }^{11}$ We did not find any evidence that the decision of the Commonwealth Court to reduce the basic wage by $10 \%$ in 1931 affected the real wage. This result provides some support for those who have questioned the effectiveness of the Court's action, such as Gregory et al (1988a). ${ }^{12}$

In the price mark-up equation, the mark-up was found to be responsive to demand variables after a lag of two years, in contrast to the one-year lag found for postwar Britain by Layard and Nickell (1986). This suggests a slow adjustment of mark-ups to changing demand conditions. An additional price equation is needed to explain the real RPI. A fall in the real price of exports, therefore, raised the real RPI and hence the real wage, as noted by Eichengreen (1992). In estimating this equation a dummy variable was included for 1929/30 to take account of a lack of consistency between the RPI and the final expenditure deflator pointed out by Butlin (1977).

\section{Section VI Conclusion}

Our main conclusion is that demand shocks were the principal cause of the rise in unemployment in the recession and its decline in the recovery. The demand factors on which we focus are changes in the terms of trade and changes in government spending, which were closely related to capital inflows. This result shows up very strongly.

By contrast the role of real wages is less clear cut. We find that the real product wage has a well-determined coefficient in the employment equation and that there is a strong link 
between the real wage and the real consumer price index, that is the RPI deflated by the output price. The coefficient on the real RPI is a measure of real wage resistance, which is attributable to the wage indexation arrangements for adjusting money wages. This meant that falling export prices aggravated the downturn, as claimed by Eichengreen (1992). While fluctuations in real export prices affected the real wage and unemployment, this effect was far weaker than the impact of demand shocks in both depression and recovery. In addition indexation arrangements virtually eliminated nominal wage rigidity. Nominal inertia was a major contributor to unemployment in countries, such as in terwar Britain, which relied on orthodox collective bargaining. Australia gained from its greater flexibility of money wages, which meant that nominal inertia was not a source of unemployment. ${ }^{13}$

We also found that the real wage was responsive to unemployment, in contrast to the findings of other researchers, such as Valentine (1988), Gregory et al (1988a). We did not, however, find any evidence that the attempt of the Commonwealth Court to reduce the real basic wage by $10 \%$ in 1931 was effective. Finally, since broadly similar factors explain the downturn and the upturn, it may not be necessary to invoke additional elements, such as protection or structural change, to explain the recovery, as suggested by Schedvin (1970). 


\section{Data and Sources}

CEMP Civil employment 000s, Butlin (1977) Table IV.

K Gross capital stock (excluding housing), \$m at 1966/1967 prices, Butlin (1977) Tables IV.8 and IV.10.

W Average annual male earnings in manufacturing \$, Withers et al (1987) Lab 201.

P Total final expenditure deflator at market prices, $1966 / 67=1.00$, calculated from Butlin (1977).

Pim Price of imports at market prices index number, 1966/67 $=1.00$, Butlin (1977) Tables IV.1 and IV.3.

GOV Government expenditure on goods and services at constant prices, 1966/67 $=1.00$, Butlin (1977) Table IV.3.

TT Terms of trade, price of exports/price of imports at factor cost, Bambrick (1973).

L Labour force, workforce including armed forces 000s, Butlin (1977) Table IV.5.

AW Average award wage, minimum weekly wage of male adults \$ per week, Withers et al (1987) Lab 123.

U Unemployment rate \% Butlin (1977), Table IV.5.

MM Change in the proportion of employment in manufacturing and construction to. total employment, Butlin and Dowie (1969).

Pex Price of exports index number, 1966/67 = 1.00, Butlin (1977) Tables IV.1 and IV.3.

TUD Trade union density male and female, \% Bain and Price (1980) Table 5.1.

CA Current account of balance of payments, \$, McLean (1968).

KI Capital inflow, sum of private and public borrowing. \$, Butlin (1977) Table IV.17.

GDP GDP at constant 1966/67 prices, Butlin (1977) Table IV.3.

NGDP GDP at current prices, Butlin (1977) Table IV.1.

RPI Retail price index, 1966/67 = 1.00, Butlin (1977) Table 111.12 C series.

WT Volume of world trade, Maddison (1962). 


\section{References}

Bain, G.S. and Price, R. (1980), Profiles of Union Growth: A Comparative Statistical Portrait of Eight Countries. Blackwell, Oxford.

Bambrick, S. (1973), 'Australian price levels, 1890-1970', Australian Economic History Review 13, 57-71.

Beenstock, M. and Warburton, P. (1986), 'Wages and unemployment in interwar Britain', Explorations in Economic History, 23, 153-172.

Benjamin, D.K. and Kochin, L.A. (1979), 'Searching for an explanation of unemployment in interwar Britain', Journal of Political Economy 87, 441-78.

Boehm, E.A. (1993), Twentieth Century Economic Development in Australia 3d edn. Longman Cheshire, Melbourne.

Butlin, N.G. (1962), Australian Domestic Product, Investment and Foreign Borrowing, 18611938/9. Cambridge University Press, Cambridge.

Butlin, N.G. and Dowie, J.A. (1969), 'Estimates of Australian workforce and employment, 1861- 1961', Australian Economic History Review 9,138-55.

Butlin, N.W. (1977), 'A preliminary annual database 1900-01 to 1973-4', Research Discussion Paper No. 7701. Reserve Bank of Australia, Sydney.

Campos, J. and Ericsson, N.R. (1990), 'Economic modelling of consumers expenditure in Venezuela', mimeo, Board of Governors of the Federal Reserve System, Washington, DC (June).

Copland, D. (1934), Australia in the World Crisis 1929-33. Cambridge University Press, Cambridge.

Dimsdale, N.H. and Horsewood, N. (1996), 'The causes of unemployment in interwar Australia', Working Paper in Economic History No. 193. The Australian National University, Canberra.

Dimsdale, N.H., Nickell, S.J. and Horsewood, N. (1989), 'Real wages and unemployment in Britain during the 1930s', Economic Journal, 99, 271-92.

Eichengreen, B. (1988), 'The Australian recovery of the 1930s in international comparative perspective' in Recovery from the Depression: Australia and the World Economy in the 1930s, edited by R.G.Gregory and N.G.Butlin. Cambridge University Press, Cambridge.

Eichengreen, B. (1992), Golden Fetters: the Gold Standard and the Great Depression 19191939, Oxford University Press, New York.

Forster, C. (1990), 'Wages and wage policy: Australia in the Depression 1929-34', Australian Economic History Review, 30, 3-42. 
Giblin, L.F. (1951), The Growth of a Central Bank. Melbourne University Press, Melbourne.

Gregory, R.G. (1988), 'An overview' in Gregory and Butlin.

Gregory, R.G. and Butlin, N.G. (eds.) (1988), Recovery from the Depression: Australia and the World Economy in the 1930s. Cambridge University Press, Cambridge.

Gregory, R.G., Ho, V. and McDermott, L. (1988a), 'Sharing the burden: the Australian labour market during the 1930s' in Gregory and Butlin.

Gregory, R.G., Ho, V., McDermott, L. and Hagan, J. (1988b), 'The Australian labour market during the Thirties', in B. Eichengreen and T.J. Hatton (eds) Interwar Unemployment in International Perspective. Kluver, Dordrecht.

Hancock, K. (1969), 'The wages of the workers', Journal of Industrial Relations, 11, 17-3 8.

Hancock, K. (1979), 'First half century of Australian wage policy', Part 11 Journal of Industrial Relations, 129-60. Reprinted in Australian Labour Economics (1984) B.J. Chapman, J.E. Isaac and J.R. Niland. (eds.) Macmillan, Melbourne.

Howson, S. (1975), Domestic Monetary Management in Britain 1919-1938. Cambridge, University Press, Cambridge.

Hawke, R.G. (1988), 'Depression and recovery in New Zealand' in Gregory and Butlin.

Jonson, P.D. and Stevens, G.R. (1983), 'The 1930s and the 1980s: some facts', Research Discussion Paper, No. 8803. Reserve Bank of Australia, Sydney.

Kenwood, A.G. (1995), Australian Economic Institutions since Federation: An Introduction. Oxford University Press, Melbourne.

Layard, P.R.G. and Nickell, S.J. (1986), 'Unemployment in Britain' in C. Bean, R. Layard and S. Nickell (eds) The Rise in Unemployment. Blackwell, Oxford.

Layard, P.R.G., Nickell, S.J. and Jackman, R. (1991), Unemployment: Macroeconomics Performance and the Labour Market. Oxford University Press, Oxford.

McLean, I.W. (1968), 'The Australian balance of payments on current account 1901 to 1964 5', Australian Economic Papers, 7,77-90.

Maddison, A. (1962), 'Growth and fluctuations in the world economy 1870-1960', Banca Nazionale del Lavaro Quarterly Review, 61, 127-95.

Manning, A. (1993) 'Wage bargaining and the Phillips curve: the identification and specification of aggregate wage equations' Economic Journal. 103, 98-118.

Pincus, J.J. (1988), 'Australian budgetary policy in the 1930s' in Gregory and Butlin. 
Reddaway W.B. (1938) 'Australian wage policy, 1929-37' International Labour Review 77, reprinted in Australian Labour Economics: Readings (1967) J.E. Isaac and C.W.Ford (eds.). Sun Books, Melbourne

Schedvin, C.B. (1970), Australia in the Great Depression. Sydney University Press, Sydney.

Shann, E.O.G. and Copland, D.B. (1931), The Crisis in Australian Finance 1929-31. Angus and Robertson, Sydney

Siriwardana, M. (1995), 'The causes of the Depression in Australia in the 1930s: A general equilibrium evaluation', Explorations in Economic History 32, 51-81

Snooks, G.D. (1988), 'Government unemployment relief in the 1930s: aid or hindrance to recovery' in Gregory and Butlin.

Valentine, T.J. (1987), 'The causes of the Depression in Australia', Explorations in Economic History 24, 43-62.

Valentine, T.J. (1988), 'The Battle of the Plans: a macroeconomic model of the interwar economy' in Gregory and Butlin.

Walker, E.R. (1993), Australia in the World Depression. P.S. King, London.

Withers, O., Endres, A.N. and Perry T.N. (1987), 'Labour' in Australians: Historical Statistics, W. Vamplew (ed), Fairfax, Syme and Weldon Associates, Broadway, NSW. 


\section{Notes}

1 A useful survey of the Australian economy in this period is provided by Johnson and Stevens (1983). The role of Australia as a primary producer in an international context is discussed in Eichengreen (1993).

Annual data end in June of each year.

3 During the 1920s the growth of the labour force was increased by a high rate of immig ration. The average rate of migration was 6 per 1,000 of population from 19215 and 4 form 1926-30, representing 25-30\% of the annual average increase in the population. The Great Depression checked the inflow of labour causing the virtual disappearance of net migration, Boehm (1993) Table 3.3.

$4 \quad$ Wool exports averaged $43 \%$ of merchandise exports by value in the 1920 s falling to $36 \%$ in the 1930s, Boehm (1993), Table 4.1.

5 The external and internal aspects of the crisis are distinguished by Schedvin pp.210, 250- 3 .

6 Real wage resistance is discussed in Layard, Nickell and Jackman pp 107-109, pp 209-211. Workers seek to protect themselves against exogenous changes, which reduce living standards. The formal indexation arrangements in Australia implied that real wage resistance would be permanent and not temporary. This is a feature of a long-standing conventional incomes policy, p 484.

Gregory (1988a) criticizes Valentine's (1988) wage variable for the use of a deflator including export prices. Export prices are included in the TFE deflator, which we use, but the terms of trade variable serves to correct the real wage for changes in the prices of internationally traded goods. Hence our employment equation is not subject to the same criticism. In general our results supports Valentine's position.

8 The role of import prices in the wage equation is much reduced in Australia compared with Britain. In the normal model with wage setting by collective bargaining the coefficient on real import prices would be expected to be positive as workers seek higher real wages to compensate for a higher cost of living. This is found for post war Britain in Layard and Nickell (1986). However for interwar Britain the sign in the real import coefficient is positive, suggesting that workers were overcompensated in terms of higher wages for falling real import prices in the depression of the 1930s, Dimsdale et al (1989).

Trade union density was high in interwar Australia by international standard. In 1929 it was $45.7 \%$ compared with $31.1 \%$ in the UK and $9.3 \%$ in the US, Bain and Price 
(1980). The high degree of control of arbitrating bodies over wage determination in Australia appears to have reduced the scope for trade union density to act as an explanatory factor in the wage equation.

10 The long lags on the demand variables in the price mark-up equation assist the identification of the wage equation. Lags in the demand variables in the price setting process indicate a different process of adjustment for prices as compared with wages. This reduces the identification problem which can arise in this model, Manning (1993).

11 On the development of schemes for the relief of unemployment, see Johnson and Stevens (1983) and Snooks (1988).

12 Our results point to the failure of the Commonwealth Court's attempt to reduce real wages but do not explain why the Court's decision was ineffective. On this issue see Gregory et al (1988a) and Foster (1990).

13 Siriwardana (1995) has examined the causes of the depression of the 1930s in Australia, using a computable general equilibrium model. He also finds that the drying up of capital inflow and the fall in export prices contributed to the downturn. The real wage had an adverse effect on unemployment but is not endogenous as in our model. 